\title{
Isolation and characterization of Rhizobium meliloti Tn5 mutants showing enhanced symbiotic effectiveness
}

\author{
Larissa A. Sharypova, Olga P. Onishchuk, Olga N. Chesnokova, \\ Julia G. Fomina-Eshchenko and Boris V. Simarov \\ Author for correspondence: Larissa A. Sharypova. Tel: +78124762891 . Fax: +78124704362. \\ e-mail:simarov@riam.spb.su
}

All-Russian Research Institute for Agricultural Microbiology, Podbelsky Shaussee 3, St PetersburgPushkin 6, 189620 Russia

\begin{abstract}
A series of Tn5-induced mutants which showed enhanced symbiotic effectiveness (Eff ' ) was isolated from Rhizobium meliloti strains CXM1-105 and CXM1-188. Alfalfa plants inoculated by the Eff ${ }^{-+}$mutants had significantly higher shoot dry mass than plants inoculated by the parental strains. In the greenhouse, the most effective mutants increased the shoot dry mass of the host plants by $23-26 \%$ and plant total nitrogen by $23-27 \%$. Interestingly, the frequency of the Eff ${ }^{-\cdots}$ mutants in strain CXM1-188 was higher than in the strain CXM1-105 (1.1\% versus $0.4 \%)$; this was also the case for the auxotrophic mutants (1.2\% in CXM1-188 versus $0.3 \%$ in CXM1-105). Genetic analysis of the mutants showed that the enhanced symbiotic effectiveness was cotransducible with Tn5. By the use of Southern hybridization and plasmid transfer, it was found that ten Tn5 insertions were located in the chromosome, five in megaplasmid 1, and six in megaplasmid 2.
\end{abstract}

Keywords: Rhizobium meliloti, symbiotic effectiveness, nitrogen fixation, $\operatorname{Tn} 5$ mutants

\section{INTRODUCTION}

The study of the nodule bacterium Rbizobium meliloti has proved to be very helpful in elucidating the Rbirobiumlegume symbiotic interaction. The efforts of various laboratories, focussing mainly on two R. meliloti strains, have revealed numerous genes encoding the formation and functioning of nitrogen-fixing nodules (for a review, see Martinez et al., 1990). However, it remains unclear which genes are responsible for the practically important trait of symbiotic effectiveness. The symbiotic effectiveness is usually measured by the increase of the host plant's growth, at the expense of nitrogen fixation in the root nodules.

It is well documented that random mutation and genetic recombination give rise to isolates with improved symbiotic properties (Feodorov \& Simarov, 1987; Maier \& Brill, 1978; Shukla et al., 1989; Williams, 1981). To our knowledge, only one attempt has been made to identify genes which, when mutated, enhance the symbiotic effectiveness of R. meliloti (Plazinski, 1981). Unfortunately, the author could not correlate a mutation which led to this phenotype with a $\operatorname{Tn} 5$ insertion, and failed to locate either in the R. meliloti chromosome. It was proposed that the target gene was in one of the indigenous plasmids of strain 41 .

At the biochemical and physiological level, the symbiotic effectiveness of Rhizobium has been presumed to be determined by the concerted expression of nitrogenase and complementary functions, such as hydrogen recycling (Evans et al., 1987), transport of $\mathrm{C}_{4}$-dicarboxylates into bacteroids (Birkenhead et al., 1988; Engelke et al., 1987), bacteroid respiration (Soberon et al., 1989), constitutive nod gene expression (Spaink et al., 1989), etc. Therefore, some researchers believe that Rhizobium strains could be improved through the manipulation of genes involved in the control of these functions, e.g. gene nif $A$, which encodes a positive regulator for the expression of nif/fix (nitrogen fixation) genes (Ronson et al., 1990).

It is of interest to ascertain which genes are randomly mutated when $R$. meliloti strains are selected for their improved symbiotic effectiveness, and to determine which of these genes is associated with already-known symbiotic functions. The work described here may be considered as the first step in this task. We isolated a series of Tn 5 mutants which showed an enhanced symbiotic effectiveness $\left(\mathrm{Eff}^{++}\right)$, analysed the mutants by transduction and localized the $\operatorname{Tn} 5$ insertions in the $R$. meliloti genome. 
Table 1. Bacterial strains and plasmids

\begin{tabular}{|c|c|c|}
\hline Strain or plasmid & Relevant characteristics & Source or reference \\
\hline \multicolumn{3}{|l|}{ Strains } \\
\hline \multicolumn{3}{|l|}{ Rbizobium meliloti } \\
\hline CXM1 & Spontaneous $\mathrm{Sm}^{\mathrm{r}}$ mutant of commercial strain $425 \mathrm{a}$ & Zaretskaya (1976) \\
\hline CXM1-105 & $\mathrm{Eff}^{++}$mutant of CXM1, induced by UV light & Feodorov \& Simarov (1987) \\
\hline CXM1-188 & $\mathrm{Eff}^{++}$mutant of CXM1, induced by UV light & Feodorov \& Simarov (1987) \\
\hline ZB121 & $\mathrm{Exo}^{-} \mathrm{Nod}^{-}$deletion mutant of AK631, $\mathrm{Rf}^{\mathrm{r}}$ & Banfalvi et al. (1981) \\
\hline L5-30 & Non-lysogenic strain, used for propagation of phage $\phi \mathrm{M} 12$ & Kowalski (1970) \\
\hline \multicolumn{3}{|c|}{ Agrobacterium tumefaciens } \\
\hline UBAPF2 & Plasmid-free derivative of strain LBA275 & Hynes et al. (1986) \\
\hline \multicolumn{3}{|l|}{ Eschericbia coli } \\
\hline S17-1 & $\begin{array}{l}\text { pro res mod } \mathrm{pRP} 4-2(\mathrm{Tc}:: \mathrm{Mu})(\mathrm{Km}:: \mathrm{Tn} 7) \text { integrated into the } \\
\text { chromosome, } \mathrm{Tp}^{\mathrm{r}} \mathrm{Sm}^{\mathrm{r}}\end{array}$ & Simon et al. (1983) \\
\hline \multicolumn{3}{|l|}{ Plasmids } \\
\hline pSUP2021 & pSUP202: : Tn 5, $\mathrm{Ap}^{\mathrm{r}} \mathrm{Cm}^{\mathrm{r}} \mathrm{Kr}^{\mathrm{r}}$ & Simon et al. (1983) \\
\hline pSUP5011 & pBR325: : $\operatorname{Tn} 5-m o b, \mathrm{Ap}^{\mathrm{r}} \mathrm{Cm}^{\mathrm{r}} \mathrm{Km}^{\mathrm{r}}$ & Simon $(1984)$ \\
\hline pSUP102-21 & pSUP102-Gm carrying $T n 5-\mathrm{B} 21, \mathrm{Cm}^{\mathrm{r}} \mathrm{Gm}^{\mathrm{r}} \mathrm{Tc}^{\mathrm{r}}$ & Simon et al. (1989) \\
\hline
\end{tabular}

Parts of this work were presented at the 8th and 9th International Congresses on Nitrogen Fixation (Sharypova et al., 1990; Chesnokova et al., 1993).

\section{METHODS}

Bacterial strains and culture conditions. The strains used in this work are listed in Table 1. R. meliloti and Agrobacterium tumefaciens strains were cultured in either TY medium (Beringer, 1974) or yeast mannitol medium (Allen, 1959). The Eschericbia coli strains were grown in LB medium (Miller, 1972). The antibiotics used for selection were added to the media at the following concentrations. For R. meliloti and $A$. tumefaciens: neomycin $(\mathrm{Nm}) 200 \mu \mathrm{g} \mathrm{ml}^{-1}$, tetracycline (Tc) $15 \mu \mathrm{g} \mathrm{ml}^{-1}$, gentamicin (Gm) $40 \mu \mathrm{g} \mathrm{ml}^{-1}$, streptomycin (Sm) $500 \mu \mathrm{g} \mathrm{ml}^{-1}$, rifampicin (Rf) $50 \mu \mathrm{g} \mathrm{ml}^{-1}$. For E. coli: $\mathrm{Nm} 50 \mu \mathrm{g} \mathrm{ml}^{-1}, \mathrm{Tc}$ $5 \mu \mathrm{g} \mathrm{ml}^{-1}, \mathrm{Gm} 10 \mu \mathrm{g} \mathrm{ml}^{-1}, \mathrm{Sm} 100 \mu \mathrm{g} \mathrm{ml}^{-1}$, Rf $50 \mu \mathrm{g} \mathrm{ml}^{-1}$. R. meliloti and A. tumefaciens strains were cultured at $30^{\circ} \mathrm{C}$, E. coli at $37^{\circ} \mathrm{C}$.

Genetic manipulations. Tn 5 mutagenesis and bacterial crosses were carried out as described by Simon et al. (1983). Only one mutant clone was taken from each cross. The conjugal transfer: of plasmids was performed by mixing donor and recipient: cultures (ratio 1:5) on non-selective TY or LB plates. After overnight incubation, the transconjugants were selected on the appropriate medium. Transduction was done according to Novikova \& Simarov (1983) using phage $\phi \mathrm{M} 12$, which transduces approximately $130 \mathrm{~kb}$ DNA (Finan et al., 1984). Briefly, an exponentially growing culture of the donor strair: was infected by the phage suspension with a multiplicity of infection of about 10 phage particles per cell. This mixture was grown for $12 \mathrm{~h}$. Then $0 \cdot 1$ vol. chloroform was added. The suspension was shaken at 200 r.p.m. for $30 \mathrm{~min}$ at room temperature. After centrifugation for $10 \mathrm{~min}$ at 5000 r.p.m. the water phase was transferred into sterile tubes and 0.1 vol. chloroform was added. This phage lysate, with a titre of about $10^{8}-10^{10}$ p.f.u. $\mathrm{ml}^{-1}$, was stored at $4{ }^{\circ} \mathrm{C}$. The sterility of the phage lysate was checked on rich and selective agar medium. The frequency of transduction, scored as the ratio of recom- binant cells to the total number of phage-infected recipient cells, was $10^{7}-10^{8}$ on average.

Agarose gel electrophoresis of plasmids. The method of Eckhardt (1978) as modified by Hynes et al. (1985) was used for the detection of plasmids by agarose gel electrophoresis.

Plasmid DNA isolation, hybridization probe preparation and Southern blotting. These were performed using standard protocols (Maniatis et al., 1982).

Effectiveness assays of $\boldsymbol{R}$. meliloti strains. These were performed in gnotobiotic plant tests and in greenhouse trials. In the former, alfalfa plants (Medicago varia Mart. cv. Zaikevicha) were grown in $60 \mathrm{ml}$ glass tubes containing vermiculite and $10 \mathrm{ml}$ nitrogen-free nutrient solution, as described by Provorov \& Simarov (1990). Each R. meliloti strain was used to inoculate 12 plants, two plants per tube. The shoot dry mass of 30 -d-old plants was measured after $48 \mathrm{~h}$ at $60^{\circ} \mathrm{C}$. In the greenhouse, the alfalfa plants were grown in pots which contained $5 \mathrm{~kg}$ field soil supplemented with the following nutrients ( $\mathrm{g}$ per $\mathrm{kg}$ soil): $\mathrm{FeCl}_{3} .6 \mathrm{H}_{2} \mathrm{O}, \quad 0.025 ; \quad \mathrm{KCl}, \quad 0.075 ; \quad \mathrm{KH}_{2} \mathrm{PO}_{4}, \quad 0.136 ;$ $\mathrm{MgSO}_{4} .7 \mathrm{H}_{2} \mathrm{O}, 0.123 ; \mathrm{H}_{3} \mathrm{BO}_{3}, \quad 0.003 ; \mathrm{MnSO}_{4}, 0.003 ;$ $\left(\mathrm{NH}_{4}\right) \mathrm{MoO}_{4}, 0.001$. The total nitrogen in the soil was $0.12 \%$. The soil was adjusted to a $\mathrm{pH}$ of 6.5 by the addition of $\mathrm{CaCO}_{3}$ ( $5 \mathrm{~g}$ per pot). Alfalfa seeds were surface-sterilized with $\mathrm{H}_{2} \mathrm{SO}_{4}$, rinsed and sown in the pots, 30 seeds in each pot. Immediately after this, the seeds were inoculated with rhizobia $\left(10^{9}\right.$ cells per pot). Eight replications were used per treatment. One week later, the seedlings were thinned out to leave the 13 healthiest ones in each pot. Plant shoots were cut at the beginning of the flowering period, 6 weeks after inoculation. The cutting was repeated 5 weeks later, when new shoots had reached the same stage of growth. The values for shoot dry mass and nitrogen content of both cuttings were added and used to compare symbiotic effectiveness of the Rbizobium strains.

Nodulation ability of $\boldsymbol{R}$. meliloti and $\boldsymbol{A}$. tumefaciens transconjugants. This was tested by inoculating alfalfa seedlings which were grown in $60 \mathrm{ml}$ tubes containing nitrogen-free agar medium. The concentrations of salts in this medium were the same as described by Provorov \& Simarov (1990). 
rable 2. Isolation of $\mathrm{Eff}^{++}$mutants in R. meliloti CXM1-105 and CXM1-188

Mutagenesis in CXM1-105 was performed by the use of PSUP2021; mutagenesis in CXM1-188 was performed using PSUP2021 and pSUP5011 (both vectors showed similar mutagenic activity in CXM1188).

\begin{tabular}{|c|c|c|c|c|c|c|}
\hline \multirow{3}{*}{$\begin{array}{l}\text { Parental } \\
\text { strain }\end{array}$} & \multirow{3}{*}{$\begin{array}{l}\text { Total no. } \\
\text { of colonies } \\
\text { tested }\end{array}$} & \multirow{2}{*}{\multicolumn{2}{|c|}{$\begin{array}{l}\text { No. of colonies showing } \\
\text { Eff }^{++} \text {phenotype at the }\end{array}$}} & \multicolumn{3}{|c|}{ Frequency $(\%)$ of mutants } \\
\hline & & & & \multirow{2}{*}{ Eff $^{++}$} & \multirow{2}{*}{$\mathrm{Fix}^{-*}$} & \multirow{2}{*}{ Aux* } \\
\hline & & $\begin{array}{c}\text { 1st } \\
\text { selection }\end{array}$ & $\begin{array}{l}\text { 2nd } \\
\text { selection }\end{array}$ & & & \\
\hline CXM1-105 & 1056 & 60 & 4 & $0 \cdot 4$ & $0 \cdot 2$ & 0.3 \\
\hline CXM1-188 & 2031 & 431 & 22 & $1 \cdot 04$ & 0.7 & $1 \cdot 2$ \\
\hline
\end{tabular}

*Frequencies of $\mathrm{Fix}^{-}$and auxotrophic (Aux) mutants were taken from Sharypova et al. (1987).

Nitrogen content of plants. This was determined by the use of an automatic analyser, 'Kjeltek-Auto' (Tekator, Sweden).

\section{RESULTS}

\section{Isolation of Rhizobium meliloti mutants with enhanced symbiotic effectiveness $\left(\mathrm{Eff}^{+}\right)$}

Two derivatives of a commercial $R$. meliloti strain, 425a, were used for Tn 5 mutagenesis. These strains, CXM1-105 and CXM1-188, have been shown to be more effective in nitrogen fixation than the parental strain (Feodorov \& Simarov, 1987). Previously, by the use of the suicide vectors pSUP2021 and pSUP5011 (Simon, 1984; Simon et al., 1983), a set of auxotrophic and symbiotic mutants was generated in strains CXM1-105 and CXM1-188 (Novikova et al., 1986; Sharypova et al., 1987). To isolate mutants with enhanced symbiotic effectiveness, the same pool of $\operatorname{Tn} 5$-containing prototrophic colonies was screened in the plant test.

To screen as many colonies as possible and to reduce the influence of host plant phenotypic variation on $R$. meliloti symbiotic performance, a two-step analysis was undertaken. Initially, every $\mathrm{Nm}^{\mathrm{r}}$ colony was assayed on four alfalfa plants. The shoot growth of the inoculated plants was assessed visually. Strains which caused a greater shoot mass production relative to the parental strains were studied further (Table 2). In the second step, each colony was tested on 12 alfalfa plants. This allowed a more stringent selection to be carried out. Only those strains which caused a statistically significant increase in shoot mass as compared to the parents were considered to be $\mathrm{Eff}^{++}$mutants. Twenty-six strains met this requirement (the increase in shoot dry mass ranged from 19 to $36 \%$ ). Interestingly, the frequency of the Eff ${ }^{++}$mutants was higher than the frequency of Fix mutants and nearly coincided with the frequency of auxotrophic mutants (Table 2). None of the Eff ${ }^{++}$mutants showed discernible differences from the parent in their vegetative growth or in such symbiotic traits as nodule number and rate of acetylene reduction.

It was of interest to ascertain whether $\mathrm{Eff}^{++}$mutants could enhance shoot mass under greenhouse conditions, which are less artificial than gnotobiotic ones. Fourteen mutants derived from strain CXM1-188 were chosen for the analysis (Table 3). Because of the longer period of plant growth and greater influence of environmental factors (including the soil environment, which contained combined nitrogen and indigenous Rbizobium strains), the variation in the mutants' effectiveness was higher in the greenhouse than in the gnotobiotic tests. Nevertheless, the $\mathrm{Eff}^{++}$phenotype of 10 mutants was confirmed: one mutant caused statistically significant $(P=0.05)$ enhancement in shoot mass production, another one was significantly better than the parent in nitrogen accumulation, and eight were superior to the parent in both characteristics.

\section{Transductional analysis of the Tn5-mutants which showed enhanced symbiotic effectiveness}

Since it is known that upon introduction of suicide plasmids in the $R$. meliloti genome, mutations might arise not only because of $\operatorname{Tn} 5$ transpositions (Dusha et al., 1987; Ruvkun et al., 1982), but also due to genomic rearrangements, it was necessary to analyse the genetic linkage between $\operatorname{Tn} 5$ and the mutation which caused the $\mathrm{Eff}^{++}$phenotype. By the use of bacteriophage $\phi \mathrm{M} 12$, the $\mathrm{Km}^{\mathrm{r}}$ marker encoded by $\mathrm{Tn} 5$ was transduced from seven $\mathrm{Eff}^{++}$mutants to their parental strains. The frequency of the transduction was $10^{-6}-10^{-7}$ per recipient cell. The examination of $87 \mathrm{Km}^{\mathrm{r}}$ transductants in gnotobiotic plant tests revealed that a large proportion of them were superior to the recipients in their ability to increase shoot dry mass. Thus, transductants which inherited the donor phenotype (they were significantly more effective than the recipient) comprised $52.9 \%$; those which showed intermediate effectiveness (no significant difference from either donor or recipient) comprised 36.8\%; and those which retained the recipient's phenotype (significantly less effective than the donor) comprised only $10.3 \%$ (Table 4). None of the transductants was inferior to the recipient. In all transductional crosses, except T707 $\times$ CXM1-188, the number of donor-class recombinants was higher than the number of recipient-class recombinants. 
Table 3. Symbiotic effectiveness of $R$. meliloti $\operatorname{Tn} 5$ mutants under greenhouse conditions

\begin{tabular}{|c|c|c|c|c|}
\hline \multirow[t]{2}{*}{ Strain $†$} & \multicolumn{2}{|c|}{ Shoot dry mass } & \multicolumn{2}{|c|}{ Total nitrogen } \\
\hline & $\mathbf{g}$ & $\begin{array}{c}\text { Difference from } \\
\text { parent strain } \\
(\%)\end{array}$ & mg & $\begin{array}{c}\text { Difference from } \\
\text { parent strain } \\
(\%)\end{array}$ \\
\hline CXM1-188 & $9 \cdot 35$ & 0 & 326.9 & 0 \\
\hline $\mathrm{T} 47$ & $9 \cdot 54$ & $2 \cdot 0$ & $322 \cdot 2$ & $-1 \cdot 4$ \\
\hline T129 & $9 \cdot 73$ & $4 \cdot 1$ & $327 \cdot 0$ & 0 \\
\hline T55 & $10 \cdot 06$ & $7 \cdot 6$ & $348 \cdot 1$ & $6 \cdot 5$ \\
\hline Т91 & $10 \cdot 19$ & $9 \cdot 0$ & $341 \cdot 1$ & $4 \cdot 3$ \\
\hline T868 (Chr) & $10 \cdot 35$ & $10 \cdot 7$ & $356 \cdot 3^{*}$ & $9 \cdot 9$ \\
\hline T54 (Chr) & $10 \cdot 54^{*}$ & $12 \cdot 7$ & $347 \cdot 9$ & $6 \cdot 4$ \\
\hline T707 (Chr) & $10 \cdot 75^{*}$ & $15 \cdot 0$ & $355 \cdot 8^{*}$ & $8 \cdot 0$ \\
\hline T624 (Chr) & $10 \cdot 89^{*}$ & $16 \cdot 5$ & $373 \cdot 0 *$ & $14 \cdot 1$ \\
\hline T828 (Chr) & $10 \cdot 93^{*}$ & $16 \cdot 9$ & $373 \cdot 0 *$ & $14 \cdot 1$ \\
\hline T748 (M1) & $11 \cdot 03^{*}$ & $18 \cdot 0$ & $374 \cdot 1 *$ & $14 \cdot 4$ \\
\hline T810 (M2) & $11 \cdot 06^{*}$ & $18 \cdot 3$ & $373 \cdot 3 *$ & $14 \cdot 2$ \\
\hline T841 (M1) & $11 \cdot 30^{*}$ & $20 \cdot 9$ & $372.7 *$ & $14 \cdot 0$ \\
\hline T798 (M2) & $11 \cdot 54^{*}$ & $23 \cdot 4$ & $416 \cdot 0 *$ & $27 \cdot 3$ \\
\hline T716 (M1) & $11 \cdot 64 *$ & $25 \cdot 6$ & $402 \cdot 0^{*}$ & $23 \cdot 0$ \\
\hline Uninoculated & $8 \cdot 05$ & - & $260 \cdot 1$ & - \\
\hline $\operatorname{LSD}(0.05) \ddagger$ & 1.07 & & $25 \cdot 44$ & \\
\hline
\end{tabular}

* Significantly greater than the value for CXM1-188.

$\dagger$ The location of $\operatorname{Tn} 5$ is shown in parentheses: Chr, chromosome; M1, megaplasmid 1; M2, megaplasmid 2 .

$\ddagger$ LSD (least significant difference) was calculated not only for the 16 variants presented here, but also for 59 variants which were tested in the same greenhouse experiment.

Table 4. Symbiotic phenotypes of $\mathrm{Km}^{r}$ transductants isolated from crosses between $\mathrm{Eff}^{++}$donors and wild-type recipients

Each transductant was tested on 12 alfalfa plants. T482 was crossed with its parent CXM1-105, while the other mutants were crossed with their parent CXM1-188.

\begin{tabular}{|c|c|c|c|c|c|c|c|}
\hline \multirow[t]{2}{*}{ Donor } & \multicolumn{3}{|c|}{ No. of transductants with effectiveness } & \multicolumn{3}{|c|}{ Shoot dry mass (mg) } & \multirow{2}{*}{$\begin{array}{c}\text { Pattern of } \\
\text { inheritance* }\end{array}$} \\
\hline & Of donor & Of recip. & Intermediate & Donor & Recip. & Transductants, $\bar{x}$ & \\
\hline $\mathrm{T} 482$ & 5 & 0 & 0 & $22 \cdot 0$ & $15 \cdot 6$ & $22 \cdot 8$ & $\mathrm{D}$ \\
\hline $\mathrm{T} 54$ & 7 & 0 & 2 & $19 \cdot 3$ & $14 \cdot 0$ & $19 \cdot 9$ & $\mathrm{D}$ \\
\hline T707 & 1 & 5 & 3 & $20 \cdot 6$ & $14 \cdot 0$ & $15 \cdot 9$ & $\mathrm{R}$ \\
\hline $\mathrm{T} 798$ & 19 & 2 & 21 & $18 \cdot 3$ & $14 \cdot 0$ & $18 \cdot 7$ & $\mathrm{D}$ \\
\hline T810 & 6 & 1 & 3 & $19 \cdot 5$ & $14 \cdot 0$ & $18 \cdot 2$ & $\mathrm{D}$ \\
\hline $\mathrm{T} 828$ & 4 & 0 & 1 & $19 \cdot 7$ & $14 \cdot 0$ & $20 \cdot 1$ & $\mathrm{D}$ \\
\hline \multirow[t]{2}{*}{$\mathrm{T} 868$} & 4 & 1 & 2 & $20 \cdot 2$ & $14 \cdot 0$ & $18 \cdot 4$ & $\mathrm{D}$ \\
\hline & 46 & 9 & 32 & \multicolumn{3}{|c|}{$\operatorname{LSD}(0 \cdot 05)=4 \cdot 10$} & \\
\hline
\end{tabular}

* The pattern of inheritance is denoted by ' $D$ ' (like donor type) if the rnean value for transductants is significantly greater than the value for the recipient, and has no difference from that for the donor; ' $R$ ' (like recipient type) denotes an opposite relation between the same values.

Irrespective of the variation in shoot mass, the averaged values for the transductants from all but one cross showed unambiguously the donor type of inheritance (Table 4).
This allowed the conclusion to be drawn that $\operatorname{Tn} 5$ insertions can significantly increase symbiotic effectiveness of $R$. meliloti. 


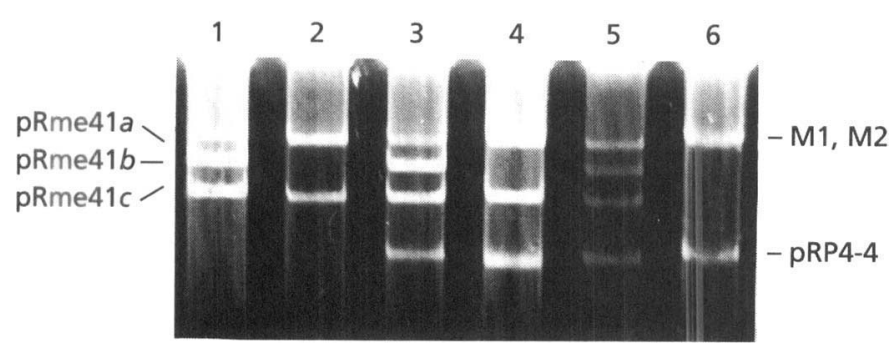

Fig. 1. Agarose gel electrophoresis of $R$. meliloti plasmids. Lane 1 , recipient strain $Z B 121$; lane 2 , a recombinant strain which acquired megaplasmid 1 from the donor; lanes 3 and 5 , recombinant strains which acquired megaplasmid 2 and pRP44; lane 4, a recombinant strain which acquired megaplasmid 1 and pRP4-4; lane 6, donor strain, which carries PRP4-4. M1, M2, megaplasmids $1,2$.

To exclude the possibility that the $\mathrm{Eff}^{++}$phenotype of transductants was caused by a genetic event other than homologous exchange between donor and recipient DNA (e.g. integration of phage DNA into the bacterial genome, or Tn 5 transpositions and associated rearrangements), transducing lysates were prepared from seven $\mathrm{Tn} 5$ containing derivatives of CXM1-105 and CXM1-188 with unaltered symbiotic effectiveness. It was found that 33 out of 35 transductants showed the same symbiotic phenotype as donor and recipient. One transductant appeared to be significantly superior to the parents, another one inferior. This allowed the estimation to be made that uncontrolled genetic events contributed about 3\% (1 out of 35 ) to the improved symbiotic phenotype.

\section{Localization of Tn5 insertions in the $R$. meliloti genome}

To localize the $\operatorname{Tn} 5$ insertions in the R. meliloti genome, cell lysates of the mutants were electrophoresed in Eckhardt gels and probed with the Tn 5 -carrying plasmid pSUP2021, which was labelled with ${ }^{32} \mathrm{P}$ (Simarov et al., 1990). The examination of 21 mutants revealed that 10 of them carried $\operatorname{Tn} 5$ in the chromosome and 11 carried it in one of the megaplasmids which comigrated in the agarose gel.

To distinguish between the megaplasmids, those which carried Tn 5 were transferred into another genetic background using the mob system described by Simon $e t$ al. (1983). A mutant which was induced by Tn5-mob and another one with an integrated plasmid pSUP2021 could readily be used as donors. Other mutants, whose megaplasmids did not contain a mob site, were conjugated with E. coli S17-1 carrying vector pSUP102-21 (Simon et al., 1989). This vector was loaded with $\operatorname{Tn} 5-21$, which allowed integration to occur at the site of $\operatorname{Tn} 5$ insertion. The frequency of such transconjugants was $10^{-4}$, while rescue of the vector markers in Tn5-free background of CXM1105 or CXM1-188 occurred at a frequency of $10^{-8}$. Following the introduction of a helper plasmid pRP4-4, the $\operatorname{Tn} 5$ mutants were conjugated with the $R$. meliloti
Table 5. Transfer of nodulation ability from Eff ${ }^{++}$ mutants to A. tumefaciens UBAPF2 and R. meliloti ZB121

\begin{tabular}{|c|c|c|c|c|}
\hline \multirow[t]{2}{*}{ Donor } & \multirow[t]{2}{*}{ Recipient } & \multicolumn{2}{|c|}{$\begin{array}{l}\text { No. of transconjugants } \\
\text { tested with the } \\
\text { following phenotypes }\end{array}$} & \multirow[t]{2}{*}{ Location* } \\
\hline & & Nod $^{+}$ & Nod $^{-}$ & \\
\hline T173 & $\begin{array}{l}\text { A. tum. } \\
\text { R. mel. }\end{array}$ & $\begin{array}{l}0 \\
0\end{array}$ & $\begin{array}{l}20 \\
20\end{array}$ & M2 \\
\hline T482 & $\begin{array}{l}\text { A. tum. } \\
\text { R. mel. }\end{array}$ & $\begin{array}{r}9 \\
10\end{array}$ & $\begin{array}{l}1 \\
0\end{array}$ & M1 \\
\hline T716 & $\begin{array}{l}\text { A. tum. } \\
\text { R. mel. }\end{array}$ & $\begin{array}{l}32 \\
35\end{array}$ & $\begin{array}{l}3 \\
0\end{array}$ & M1 \\
\hline T748 & $\begin{array}{l}\text { A. tum. } \\
\text { R. mel. }\end{array}$ & $\begin{array}{l}31 \\
45\end{array}$ & $\begin{array}{l}6 \\
0\end{array}$ & M1 \\
\hline T728 & $\begin{array}{l}\text { A. tum. } \\
\text { R. mel. }\end{array}$ & $\begin{array}{l}0 \\
0\end{array}$ & $\begin{array}{l}30 \\
20\end{array}$ & M2 \\
\hline T798 & $\begin{array}{l}\text { A. tum. } \\
\text { R. mel. }\end{array}$ & $\begin{array}{l}0 \\
0\end{array}$ & $\begin{array}{l}11 \\
19\end{array}$ & M2 \\
\hline T841 & $\begin{array}{l}\text { A. tum. } \\
\text { R. mel. }\end{array}$ & $\begin{array}{l}15 \\
13\end{array}$ & $\begin{array}{l}1 \\
0\end{array}$ & M1 \\
\hline T810 & $\begin{array}{l}\text { A. tum. } \\
\text { R. mel. }\end{array}$ & $\begin{array}{l}0 \\
0\end{array}$ & $\begin{array}{l}13 \\
21\end{array}$ & M2 \\
\hline T835 & $\begin{array}{l}\text { A. tum. } \\
\text { R. mel. }\end{array}$ & $\begin{array}{l}0 \\
0\end{array}$ & $\begin{array}{l}11 \\
12\end{array}$ & M2 \\
\hline T837 & $\begin{array}{l}\text { A. tum. } \\
\text { R. mel. }\end{array}$ & $\begin{array}{l}0 \\
0\end{array}$ & $\begin{array}{l}18 \\
10\end{array}$ & M2 \\
\hline T816 & $\begin{array}{l}\text { A. tum. } \\
\text { R. mel. }\end{array}$ & $\begin{array}{l}42 \\
11\end{array}$ & $\begin{array}{l}1 \\
0\end{array}$ & M1 \\
\hline
\end{tabular}

* M1, megaplasmid 1; M2, megaplasmid 2.

deletion mutant ZB121 (Banfalvi et al., 1981). The frequency of $\mathrm{Nm}^{\mathrm{r}}$ transconjugants was about $10^{-8}-10^{-9}$ per recipient cell. Strain ZB121 contains three plasmids which have different electrophoretic mobilities (Banfalvi et al., 1981); pRme41a, a cryptic plasmid of medium size $(210 \mathrm{~kb}) ; \mathrm{pRme} 41 b$, a derivative of the symbiotic megaplasmid 1 with a deletion larger than $135 \mathrm{~kb}$ located in a region encoding nodulation and nitrogen fixation; and pRme41c, megaplasmid 2, which according to estimations of Burkardt and co-authors (Burkardt \& Burkardt, 1984; Burkardt et al., 1987), is about $1600 \mathrm{~kb}$ in size. Hynes et al. (1986) have shown that both megaplasmids of ZB121 could be replaced by the corresponding megaplasmids of other $R$. meliloti strains. When the megaplasmids of our mutants were mobilized into ZB121, the plasmid profiles of transconjugants were in agreement with those expected for the replacement of either megaplasmid (Fig. 1). Thus, the introduction of megaplasmid 1 led to the loss of a plasmid band corresponding to $\mathrm{pRme} 41 b$, whereas the introduction of megaplasmid 2 did not alter the plasmid profile of the recipient (Fig. 1). It was found that some transconjugants acquired pRP4-4, and others did not. The 
megaplasmids marked with $\operatorname{Tn} 5$ were also mobilized to a plasmid-free $A$. tumefaciens strain UBAPF2 (Hynes et al., 1985). All transconjugants showed the same plasmid pattern: a single band corresponding to one of the megaplasmids.

In addition to the plasmid analysis, the transconjugants were examined for those phenotypic traits known to be determined by megaplasmid 1 (nodulation ability) and megaplasmid 2 (exopolysaccharide production). Both recipients $\mathrm{ZB121}$ and UBAPF2 proved to be very convenient for this purpose (Hynes et al., 1986), since they were uriable to induce nodules on alfalfa $\left(\mathrm{Nod}^{-}\right)$and, in addition, ZB121 was deficient in exopolysaccharide production $\left(\mathrm{Exo}^{-}\right)$. Following the introduction of megaplasmid 1, both recipients acquired the $\mathrm{Nod}^{+}$phenotype and showed the same exopolysaccharide production as the recipients. Following the transfer of megaplasmid 2, the transconjugants could not nodulate alfalfa, but showed altered exopolysaccharide production: ZB121 transconjugants were Exo ${ }^{+}$, while UBAPF2 transconjugants were less mucoid than the recipient. The nodulation ability of transconjugants is presented in Table 5. ZB121 transconjugants containing megaplasmid 1 restored the $\mathrm{Nod}^{+}$phenotype in addition to the $\mathrm{Fix}^{+}$phenotype. The phenotypic traits of all transconjugants tested were consistent with results obtained from the plasmid analysis of the ZB121 transconjugants. This allowed the conclusion to be made that five $\mathrm{Eff}^{++}$mutants donated megaplasmid 1, and six of them donated megaplasmid 2 . It is interesting that the mutants which showed the highest symbiotic effectiveness in the greenhouse carried Tn 5 in one of the megaplasmids, while other mutants carried the transposon in the chromosome (Table 3).

\section{DISCUSSION}

Following the introduction of $\operatorname{Tn} 5$ into two R. meliloti strains, $\mathrm{Nm}^{\mathrm{r}}$ transposants were screened for their ability to increase shoot mass of alfalfa plants grown in the absence of combined nitrogen. This allowed the isolation of mutants with improved symbiotic effectiveness. When tested in the greenhouse, eight $\mathrm{Eff}^{++}$mutants increased the shoot dry mass of the host plant by $15.0-25.6 \%$ and the plant's total nitrogen by $8 \cdot 0-23.0 \%$ (all these differences were statistically significant at $P=0.05$ ). The rate at which $\mathrm{Eff}^{++}$mutants were obtained was comparable to that of the auxotrophic mutants. This finding indicates that there are quite a number of genes which, when mutated, may enhance the $R$. meliloti symbiotic effectiveness.

Addressing the functions of the tagged genes, we propose that they are involved in the negative control of gene or protein activity. Evidence for genetic factors which suppress the effectiveness of symbiosis was supplied by the work of Pankhurst et al. (1986). They found that such a factor (or factors) was attributable to an indigenous plasmid of Rhizobium loti NZP2037. The loss of the plasmid resulted in the enhanced symbiotic effectiveness (Pankhurst $e t$ al., 1986). If a gene affected by $\operatorname{Tn} 5$ insertion was not switched off, but acquired a read-through promoter of $\operatorname{Tn} 5$, which could also be the case (Rostas $e t$ al., 1986), it is difficult to speculate about the function of the gene.

To prove that the $\mathrm{Ef}^{++}$phenotype of the mutants was caused by $\mathrm{Tn} 5$ insertions, we transduced $\mathrm{Tn} 5$ from seven mutants to the parental strains. In all but one cross, transductants showing the donor symbiotic phenotype outnumbered those which had the recipient phenotype. Thus, transductants superior to the recipient comprised $53 \%$, and those which retained the recipient's level of the effectiveness comprised $10 \%$. All other transductants could not be related definitely to either donor or recipient class, since they showed an intermediate level of effectiveness. It is known that $\mathrm{Eff}^{++}$isolates can arise fortuitously as a result of genetic exchange between two strains. All the methods of genetic transfer which account for genetic exchange in $R$. meliloti (transformation, transduction, conjugation and spheroplast fusion), were shown to result in $1.3-4.8 \% \mathrm{Eff}^{++}$recombinants (Simarov et al., 1989). In our control experiments, where transduction of $\operatorname{Tn} 5$ was performed from donors to recipients with equal symbiotic effectiveness, the frequency of the $\mathrm{Eff}^{++}$phenotype was of the same order, about $3 \%$. This frequency is substantially lower than that obtained using $\mathrm{Eff}^{++}$donors. If mutations leading to the $\mathrm{Eff}^{++}$phenotype were caused by $\mathrm{Tn} 5$ insertions and were expressed in an absolute manner (such as $\mathrm{Nod}^{-}$and $\mathrm{Fix}^{-}$), one would expect $100 \%$ of the recombinants to be of the donor class. Our mutations, however, affected symbiotic effectiveness quantitatively. Perhaps this explains why only $53 \%$ of the recombinants exhibited the $\mathrm{Eff}^{++}$phenotype. In addition, variation of alfalfa plants could mask the symbiotic potential of $R$. meliloti strains (Provorov \& Simarov, 1990).

By the use of physical and genetic methods, we located ten Tn 5 insertions in the chromosome, five in megaplasmid 1 and six in megaplasmid 2. According to these data, genes which may enhance symbiotic effectiveness by mutation are distributed over different replicons.

The enhanced symbiotic effectiveness shown by the $\operatorname{Tn} 5$ mutants was not associated with any alteration in bacterial vegetative growth, number of nodules induced or rate of acetylene reduction. However, when the plant nitrogen accumulation was measured, $\operatorname{Tn} 5$ mutants appeared to be superior to their parents. Therefore it can not be excluded that the mutants are better nitrogen fixers than the parents. On the other hand, the mutants could increase plant growth by optimization of nitrogen assimilation, or through hormone or vitamin production. The biochemical and molecular genetic characterization of the mutants will permit the mechanisms involved to be found. This is the objective of our current investigation.

\section{ACKNOWLEDGEMENTS}

We thank Alfred Pühler and Reinhard Simon for providing the SUP-vectors, pRP4-4, E. coli S17-1 and A. tumefaciens UBAPF2, and thank Adam Kondorosi for R. meliloti ZB121 and Ethan R. Signer for phage $\phi \mathrm{M} 12$. We are grateful to Inge Pretorius-Güth for reading the manuscript, and to Nicolai A. Provorov and Mathias Keller for valuable critical comments on the manu- 
script. This research was supported by the International Project 'Interbioazot-2000' (Ministry of Science and Technology of Russia) and the Russian State Programme 'Frontiers in Genetics'.

\section{REFERENCES}

Allen, O. N. (1959). Experiments in Soil Bacteriology, 3rd edn, p. 54. Minneapolis: Bugges Publishing Co.

Banfalvi, Z., Sakanyan, V., Koncz, C., Kiss, A., Dusha, I. \& Kondorosi, A. (1981). Location of nodulation and nitrogen fixation genes on a high molecular weight plasmid of Rhizobium meliloti. Mol \& Gen Genet 184, 318-325.

Beringer, J. E. (1974). R factor transfer in Rbizobium leguminosarum. $J$ Gen Microbiol 84, 188-198.

Birkenhead, K., Manian, S. S. \& O'Gara, F. (1988). Dicarboxylic acid transport in Bradyrbizobium japonicum: use of Rbizobium meliloti dct gene(s) to enhance nitrogen fixation. J Bacteriol 170, 184-189.

Burkardt, B. \& Burkardt, H. J. (1984). Visualization and exact molecular weight determination of a Rbizobium meliloti symbiotic megaplasmid. J Mol Biol 175, 213-218.

Burkardt, B., Schillik, D. \& Puhler, A. (1987). Physical characterization of Rhizobium meliloti megaplasmids. Plasmid 17, 13-25.

Chesnokova, O., Savich, N., Sharypova, L. \& Simarov, B. (1993). Fine mapping and molecular cloning of $\mathrm{Tn} 5$-mutations enhancing symbiotic effectiveness of Rbizobium meliloti. In New Horizons in Nitrogen Fixation, p. 714. Edited by R. Palacios, J. Mora \& W. E. Newton. Dordrecht: Kluwer.

Dusha, I., Kovalenko, S., Banfalvi, Z. \& Kondorosi, A. (1987). Rhizobium meliloti insertion element ISRm2 and its use for identification of the fix X gene. J Bacteriol 169, 1403-1409.

Eckhardt, T. (1978). A rapid method for the identification of plasmid deoxyribonucleic acid in bacteria. Plasmid 1, 584-588.

Engelke, Th., Jagadish, M. N. \& Puhler, A. (1987). Biochemical and genetic analysis of Rbizobium meliloti mutants defective in $\mathrm{C}_{4}$ dicarboxylate transport. J Gen Microbiol 133, 3019-3029.

Evans, H. J., Harker, A. R., Papen, H., Russel, S. A., Hanus, F. J. \& Zuber, M. (1987). Physiology, biochemistry, and genetics of the uptake hydrogenase in Rhizobia. Annu Rev Microbiol 41, 335-361.

Feodorov, S. N. \& Simarov, B. V. (1987). Isolation of mutants with altered symbiotic properties in Rbizobium meliloti by the use of UVlight. Selskokboz Biol (in Russian) 9, 44-49.

Finan, T. M., Hartwieg, E., LeMieux, K., Bergman, K., Walker, G. C. \& Signer, E. R. (1984). General transduction in Rbizobium meliloti. J Bacteriol 159, 120-124.

Hynes, M. F., Simon, R. \& Puhler, A. (1985). The development of plasmid-free strains of Agrobacterium tumefaciens by using incompatibility with a Rbizobium meliloti plasmid to eliminate pAtC58. Plasmid 13, 99-105.

Hynes, M. F., Simon, R., Muller, P., Niehaus, K., Labes, M. \& Puhler, A. (1986). The two megaplasmids of Rbizobium meliloti are involved in the effective nodulation of alfalfa. Mol \& Gen Genet 202, 356-362.

Kowalski, M. (1970). Genetic analysis by transduction of Rbizobium meliloti mutants with changed symbiotic activity. Acta Microbiol Pol $2,115-122$.

Maier, R. J. \& Brill, W. J. (1978). Mutant strains of Rbizobium japonicum with increased ability to fix nitrogen for soybean. Science 201, 448-450.

Maniatis, T., Fritsch, E. F. \& Sambrook, J. (1982). Molecular Cloning. A Laboratory Manual, p. 109. Cold Spring Harbor, NY: Cold Spring Harbor Laboratory.
Martinez, E., Romero, D. \& Palacios, R. (1990). The Rbizobium genome. Crit Rev Plant Sci 9, 59-93.

Miller, J. H. (1972). Experiments in Molecular Genetics, p. 395. Cold Spring Harbor, NY: Cold Spring Harbor Laboratory.

Novikova, N. I. \& Simarov, B. V. (1983). Isolation of Rbizobium meliloti transducing phages. Genetika (in Russian) 19, 331-332.

Novikova, N. I., Sharypova, L. A. \& Simarov, B. V. (1986). Transposon induced mutagenesis in Rhizobium meliloti strain CXM1105. Mol Genet Microbiol Virusol (in Russian) 8, 32-35.

Pankhurst, C. E., Macdonald, P. E. \& Reeves, J. M. (1986). Enhanced nitrogen fixation and competitiveness for nodulation of Lotus pedunculatus by a plasmid-cured derivative of Rbizobium loti.J Gen Microbiol 132, 2321-2328.

Plazinski, J. (1981). Tn5-inherited mutant strain of Rbizobium meliloti with a highly increased ability to fix nitrogen for lucerne. Microbiol Lett 18, 137-142.

Provorov, N. A. \& Simarov, B. V. (1990). Genetic variation in alfalfa, sweet clover and fenugreek for the activity of symbiosis with Rhizobium meliloti. Plant Breeding 105, 300-310.

Ronson, C. W., Bosworth, A., Genova, M., Gudbransen, S., Hankinson, T., Kwiatkowski, R., Ratcliffe, H., Robie, C., Sweeney, P., Szeto, W., Williams, M. \& Zablotowicz, R. (1990). Field release of genetically-engineered Rbizobium meliloti and Bradyrbizobium japonicum strains. In Nitrogen Fixation: Acbievements and Objectives, pp. 397-403. Edited by P. M. Gresshoff, L. E. Roth, G. Stacey \& W. E. Newton. New York: Chapman \& Hall.

Rostas, K., Kondorosi, E., Horvath, B., Simoncsits, A. \& Kondorosi, A. (1986). Conservation of extended promoter regions of nodulation genes in Rbizobium. Proc Natl Acad Sci US A 83, 1757-1761.

Ruvkun, G. B., Long, S. R., Meade, H. M., Van Den Bos, R. C. \& Ausubel, F. M. (1982). ISRm1 Rbizobium meliloti insertion sequence that transposes preferentially into nitrogen fixation genes. $J \mathrm{Mol}$ Appl Genet 1, 405-418.

Sharypova, L. A., Onishchuk, O. P., Novikova, N. I., Rumyantseva, T. B., Aronshtam, A. A. \& Simarov, B. V. (1987). Mutagenic activity of suicide plasmid vectors, which carry $\operatorname{Tn} 5$, in Rbizobium meliloti. Genetika (in Russian) 23, 2104-2111.

Sharypova, L. A., Fomina-Eshchenko, J. G. \& Simarov, B. V. (1990). Localization of the $\operatorname{Tn} 5$ mutations enhancing symbiotic efficiency on Rbizobium meliloti megaplasmids. In Nitrogen Fixation: Acbievements and Objectives, p. 584. Edited by P. M. Gresshoff, L. E. Roth, G. Stacey \& W. E. Newton. New York: Chapman \& Hall.

Shukla, R. S., Singh, C. B. \& Dubey, J. N. (1989). Induced genetic variability in Rbizobium leguminosarum for nitrogen fixation in Vicia faba L. Theor Appl Genet 78, 433-435.

Simarov, B. V., Novikova, N. I., Sharypova, L. A., Provorov, N. A., Aronshtam, A. A. \& Kuchko, V. V. (1989). Molecular-genetic basis for Rhizobium selection. In Interrelationships between Microorganisms and Plants in Soil, pp. 45-50. Edited by V. Vancura \& F. Kunc. Praha: Academia Publishing House of the CAS.

Simarov, B. V., Sharypova, L. A., Chesnokova, O. N., Onishchuk, O. P. \& Kuchko, V. V. (1990). Analysis of Rhizobium meliloti Tn5 mutants with enhanced symbiotic effectiveness. Genetika (in Russian) 26, 630-635.

Simon, R. (1984). High frequency mobilization of Gram-negative bacterial replicons by the in vitro constructed Tn 5-Mob transposon. Mol \& Gen Genet 169, 413-420.

Simon, R., Priefer, U. \& Puhler, A. (1983). A broad host range mobilization system for in vivo genetic engineering: transposon mutagenesis in Gram-negative bacteria. Biotechnology 1, 784-791.

Simon, R., Quandt, J. \& Klipp, W. (1989). New derivatives of transposon $\operatorname{Tn} 5$ suitable for mobilization of replicons, generation 
of operon fusions and induction of genes in Gram-negative bacteria. Gene 80, 161-169.

Soberon, M., Williams, H. D., Poole, R. K. \& Escamilla, E. (1989). Isolation of a Rbizobium phaseoli cytochrome mutant with enhanced respiration and symbiotic nitrogen fixation. J Bacteriol 171, 465-472.

Spaink, H. P., Okker, R. J. H., Wiijffelman, C. A., Tak, T., GoosenDe Roo, L., Pees, E., Van Brussel, A. A. N. \& Lugtenberg, B. J. J. (1989). Symbiotic properties of rhizobia containing a flavoroidindependent hybrid nodD product. $J$ Bacteriol 171, 4045-4053.
Williams, P. M. (1981). The isolation of effective and ineffective mutants of cowpea Rhizobium. Plant Soil 60, 349-356.

Zaretskaya, A. N. (1976). Genetic transformation as a method of alfalfa nodule bacteria improvement. Mikrobiologiya (in Russian) 46, 737-740.

Received 23 April 1993; revised 20 September 1993; accepted 1 October 1993. 